\title{
INTERMEDIARIES AND PERSONAS: A RADICAL RHETORICAL READING OF MARKETING WORK
}

\author{
Chris Miles Bournemouth University
}

\begin{abstract}
This article examines the various ways in which marketing work (in both 'practice' and scholarship) engages with the construction of personas. It positions marketing as a rhetorical enterprise concerned with the establishment of intermediary and liminal positions within society; positions which are designed, as in Jung's description of the persona, to "make a definite impression upon others [....and...] to conceal the true nature of the individual" (Jung 1972, p. 192) in order to facilitate social integration. An initial close reading of Jung's work on the persona provides the context for a portrayal of the extreme tensions between organisational/disciplinary/professional identity and persona in modern marketing work. The article examines the long history of anxiety that marketers have manifested regarding the reputation of their practice, the 'morality' and 'scientific' ethos of their unavoidably relativistic approach to truth and identity, and their focus on the construction of appearance/persona for commercial or political advantage. Finally, if the urge to create personas comes from needing to consistently portray the roles that society expects us to adopt (whether that be parson, cobbler or poet, to use Jung's examples), what happens to a discipline and profession which is so focused on the dynamic re-creation, re-assignment and re-invention of personas? The work argues that the distrust that marketing experiences at the hands of mainstream society illustrates the way in which the maintenance of a consistent persona, 'standing at one's post' (to use Jung's terminology), remains one of the most uncomfortable and contested aspects of modern life.
\end{abstract}

\section{KEY WORDS}

Jung; Persona; Marketing; Value; Rhetoric; Suspicion

\section{INTRODUCTION}

The current American Marketing Association definition of marketing provides us with a clear understanding of what lies at the core of the profession: "Marketing is the activity, set of institutions, and processes for creating, communicating, delivering, and exchanging offerings that have value for customers, clients, partners, and society at large" (AMA 2019).

In particular, the part of marketing that we, as consumers, have the most contact with is the creation and communication of offerings that have value. Marketing needs to communicate to us the value that we could have from buying the product, using the service, adopting the brand. As a result, at the core of the marketing function is the construction of the "value proposition" (Lanning \& Michaels 1988), the promise of how your life will benefit by use of the product. 
Predominantly, this 'value' comes down to the ability to help build a persona or to make one's current persona more effective, more accepted, to make it feel more fitting. Drink Coca-Cola and you will become a person who fits in with their social surroundings; fly Cathay Pacific and you will be the sort of person who is at ease with and knowledgeable about international travel; come to Newcastle University and you will be the sort of person who knows how to make a difference to the world (as its current slogan promises). The promise of marketing, precisely because it is always a promise to a consumer, is a promise about persona. An example of this would be the way in which many modern brands try to build personas around rebelliousness: "Nike with the African-American ghetto, Harley with outlaw bikers, Volkswagen with bohemian artists, Apple with cyberpunks, Mountain Dew with slackers" (Woodside et al. 2012, p. 599). The value propositions for all of these brands promise the ability to take on, through consumption, the particular variant on the rebel persona that they have sought to specialise in.

Through the creation and communication of such promises the marketer constructs and directs the transformative rituals of modern society, controlling the magic of consumption, weaving it into every aspect of our lives, helping us through each and every one of life's trials and rites of passage (Belk 1991; Belk et al. 1989; Belk et al. 2003; Otnes \& Scott 1996). This, of course, places the marketer in an incredibly powerful position in modern society, somewhat akin to that previously afforded by Joseph Campbell (2008) to the psychoanalyst, whom he dubbed the "modern master of the mythological realm, the knower of the secret ways and words of potency" (p. 6). It is the marketer, then, who provides the mythologies and paraphernalia that enable us all to build and maintain our personas on the ever-shifting, complex stages of society (Williams 1980; Williamson 2002; Jhally 1990).

Yet, along with this power does not come adulation, affection, or even respect. Instead, the marketer is mistrusted and blamed. Advertising agents regularly inhabit the murky bottom of Edelman's yearly trust barometer of professions and a myriad of social problems are laid at their door; from the increase in obesity (Critser 2003; Moss 2013; Schlosser 2002) and the scourge of cancer (Malkan, 2007), to "the destruction of long-standing cultural values and traditions" (Layton, 2011), the drive to consume above all else (Klein 2009; Ewen 2001), and the unbearable emptiness of everyday life (Williams 1980). As a result, as consumers, we find ourselves fighting back against this malevolent influence with what Heath et al. (2017, p. 1281) call an "everyday resistance to marketing".

Furthermore, business itself has traditionally treated marketing with an equal amount of suspicion. The marketing budget is the first thing to go when times get tough, the marketing department is often treated with disdain by the rest of the organization, and the need for a CMO (Chief Marketing Officer) is still not widely recognised even in Fortune 500 companies (Nath \& Mahajan 2008; Germann et al. 2015). Marketing scholars at business schools and university departments can also be seen to manifest a discomfort with the realities of the profession they study. There have been calls since at least the late 1970s for a move away from the traditions of consumer manipulation, hyperbole, and the rampant promotion of consumption at all costs. Highly influential perspectives such as the Nordic school of service marketing (Gronroos 1994, 2004, 2011; Gummesson 1987, 2008), relationship marketing (Duncan \& Moriarty, 1998) and the Service-Dominant Logic (Vargo and Lusch 2004, 2017) have argued that marketing needs to change its fundamental nature and instead dedicate itself to building long-term relationships with consumers based upon the careful, socially-aware provisioning of co-created value. Yet, these calls for change have had little effect on day-to-day marketing practices which continue to find new ways to manipulate and co-opt the consumer (Beltramini 2003; Blackshaw 2008; Miles 2016; Sasser 2008; Zwick \& Bradshaw 2019). 
There are, undoubtedly, many reasons for this general mistrust of the profession even by those who ostensibly make use of it to increase competitiveness and generate sales. However, this work will argue that underlying all these reasons is a deep unease with an occupation that seems to play so fast and loose with the idea of personas. Exploring the ways in which marketing manipulates and engineers personas will allow us insights into much of what drives our reaction against it and will also enable us to locate with greater nuance some of the fundamental tensions in contemporary society.

In order to construct its argument, this article starts first by reminding us of the way in which Jung defines the persona in terms of the part one plays in society. This sets the scene for an examination of the earliest discussion of the role of the marketer in Western thinking, namely Plato's efforts to first integrate and then quarantine the marketing function in his plan of the ideal city state. The historical turn here demonstrates that discomfort with the marketer's role is as old as the role itself, but also provides us with an ur-critique of the marketing function that revolves around the marketer's lack of legitimate role, a lack which is explicitly linked by Plato with a worry of how the marketer can infect those with legitimate, valuable roles in the city with a form of obsession that causes them to forget and forego their proper duties and instead become consumed by the marketplace. From this position we then move on to a consideration of the remarkably similar objections raised by Plato against the Sophist teachers. Sophists are just as dangerous for society as marketers because they do not abide by a legitimate role in society, they adopt expertise and positioning as an argument needs - both marketers and Sophists are not, as we might now say, 'authentic', because they do not have fixed personas. The argument then develops the similarities between the Sophist approach to argument and the marketing approach to the promise and introduces the Jungian concept of anima/us to help bind the two perspectives together, explicating the market as a manifestation of the frightening, unpredictable, ever-changing anima. Finally, it concludes by proposing that marketing seeks to keep us in an ever-collapsing dance between persona and anima, between our need for a role in society and a desire to understand and experience the Other within us. While this serves to maintains us in our constant reproduction of the persona of the consumer it threatens to prevent us from knowing, and effectively integrating, our own Other.

\section{PERSONA \& MARKETING - THE HISTORICAL DRAMA}

The persona is, Jung (1972) reminds us, "nothing real: it is a compromise between individual and society as to what a man should appear to be". It is a "compromise formation, in making which others often have a greater share than he". The persona "is a function for adapting the individual to the real world" and "occupies a place midway between the real world and individuality" (p. 507). It is also important to remember that Jung explains how the mask of persona aids, through its structural origins in the collective unconscious, the generation of personal prestige (p. 237), an element that marketing has become increasingly concerned with over the twentieth and twenty-first centuries (Vigneron \& Johnson 1999). For Jung, society demands the construction of a persona from us all - we must have our parts to play, our roles to act. As he notes, "each must stand at his post, here a cobbler, there a poet", "the average man the only kind society knows anything about - must keep his nose to one thing in order to achieve anything worthwhile" (1972, p. 305). So, the persona is a necessity of our social lives, a means by which we may guarantee for others valuable predictability and through which we may also garner the social rewards of reputation. Of course, and this is Jung's real interest, the creation and maintenance of this persona "is a very fruitful source of neuroses" (p. 307).

The necessity of adopting and consistently maintaining a particular role in society is also at the heart of Plato's theories of how the ideal city is to be organised. Importantly, Plato 
connects the necessity of social roles with the concept of a person's 'nature' and then uses these two ideas to discuss the role of the marketer in the city in a manner that provides us with a rich foundation on which to develop a theory of the relationship between the persona and suspicion of the market and its functionaries.

Plato's works are brimming with arguments about what makes a particular person inhabit a particular role or persona in society - what makes a doctor a doctor, a lawyer a lawyer, the head of a household a head of a household, or (most crucially) a philosopher a philosopher. Indeed, he made two very substantial attempts at systematising social roles in the Republic and the Laws, middle- and late-career attempts to build models of how Plato's ideal city republic should function - "to create a city in theory from its beginnings" (Republic, 369c)i as he has it in the Republic. Now, essential to the proper working of this city is that people understand their roles and give their full attention to them. Plato, in the persona of Socrates of course, takes a highly pragmatic approach to social roles: "we aren't all born alike", he says, we can all recognise that "each of us differs from somewhat in nature from the others" and one of us might be "suited to one task, another to another" (370b). Furthermore, we all do a better job if we practice one craft rather than many, because "the doer must pay close attention to his work rather than treating it as a secondary occupation" (370c). On this basis, Plato proceeds to found a huge and complex city state where every person has their place, and must "work all his life at a single trade for which he had a natural aptitude and keep away from all the others, so as not to miss the right moment to practice his work" (374c). Our role in the city, in society, is determined by our "nature" (phusis) and following that nature, making its development into the appropriate profession or calling, is what will enable each of us to "produce fine work", or, to recall Jung's words, "to achieve anything worthwhile". In Plato's theory of psychological "nature", we are not being true to our individual nature if we do not attend closely and consistently to the role in society that is appropriate to us. There is much to say, perhaps, about the differences between Plato's conception of the soul and Jung's portrait of the persona/anima relationship - but, for the purposes of this work, the above theory of social role as an expression of personal "nature" is important for how it develops into Plato's account of the introduction of the marketer to the city.

Continuing with his argument that it is an individual's nature which determines their role in society, Plato explains that those who exploit their knowledge of a particular craft or skill, such as farmers and cobblers should not be "sitting idly in the marketplace" (371c) waiting for people to come along and buy their wares. This is a waste of their time (and their nature). So, Plato notes that "there'll be people who notice this and provide the requisite service" - who will dedicate their time to staying in the market "exchanging money for the goods of those who have something to sell and then exchanging those goods for the money of those who want them" (371d). So, in "well organised cities" these people will be "those whose bodies are weakest and who aren't fit to do any other work" (371d). Interestingly, this means that these people, the intermediaries of the market, fit into society not by following or expressing their inner nature (phusis) but by reacting to their accidental physical, bodily situations. There is a lot going on under the surface here, not the least of which is the influence of an educated Athenian's predictable disdain for the merchant. However, Plato continued to develop his thinking about those who sit and wait in the marketplace through his career. By the time of the writing of the Laws, Plato's thinking about these intermediaries has evolved to focus around the poisonous allure of the market. He portrays merchants and retailers as a vector for a dreadful disease (nosos) that can threaten the well-organised city (919c) - a disease originating in the fear of poverty and the corruption of luxury and which drives those who interact with the market to lie to their customers, exaggerate the quality of their products, adulterate their wares to increase profit, etc. Plato's solution is not inoculation (through education, for example) but quarantine. 
Only resident aliens and foreigners are to be allowed to engage in retail trading in the city (920a). This way "trade should be made over to a class of people whose corruption will not harm the state unduly" (919c).

So, the role of market intermediary (or 'middle man' as marketers used to be called at the start of the twentieth-century) is one best suited to those in some way outside society whose 'nature' doesn't really matter, or is not worth considering. The way in which Plato talks about the infecting nature of the market is very similar to the way in which Jung describes the disrupting disjunction of anima (the inner bridge to the unconscious) and persona. For Plato, the market takes advantage of the upstanding citizen's appetites, whipping them into a froth of greed and undercutting their rational, civic function - it makes a mockery of their persona and therefore disrupts society at large. Engaging in marketing is something therefore that needs to be done by those for whom a 'natural' role in society is absent or without fixity. Plato, contraJung, wants a society where everyone identifies completely with their persona, their role. The market threatens this project because engaging with it draws out the anima and makes it plain that we are not our personas.

Jung warns that "a man cannot get rid of himself in favour of an artificial personality without punishment" (1972, p. 307). Plato's distrust of the market and his ultimate exclusion of its intermediaries from the citizenry reflects a telling recognition of the constantly upswelling force of the anima that must consume all. From a psychoanalytical perspective, we might even say that Plato's treatment of the market and its intermediaries is a projection of his fears of the anima - the weak, vague 'self' forever drawn to cheating and dissembling and which needs to be kept firmly away. To see how Plato's treatment of the marketing intermediary prefigures the modern suspicion of the marketer, it will help us to look at another group of people whom Plato treated in a strikingly similar fashion for very similar reasons, the Sophists.

\section{THE SOPHISTS AND THE MARKETER}

The Sophists were a group of orators, philosophers, and educators who flourished in Ancient Greece in the $5^{\text {th }}$ and $4^{\text {th }}$ centuries BCE (O'Grady 2008). While the root word, sophos, means 'wise' and 'knowledgeable', the figure of the Sophist has come down to us as someone who is manipulative and untrustworthy with words, who can make both sides of an argument equally persuasive (and so equally suspicious). Indeed, a central part of Sophistic education was the practice of dissoi logoi, where one first argues for a particular case and then against it in order to train one's skills of persuasion and argumentation. While a tremendously powerful learning tool, excellent for training young citizens for the rough and tumble of Athenian legal and political life, it betrays an attitude to absolute truth that laid it open to charges of opportunism and immorality. The Sophists' distinctly negative reputation is now generally acknowledged to have been the result of Plato's portrayal of them in his own works. The Sophists were Plato's main competitors in the $5^{\text {th }}$ century BCE Athenian knowledge market and much of the energy that he spends across his writing in making various Sophist figures appear morally suspect and argumentatively flawed is the result of him trying to establish and protect his brand in a highly competitive market (Cole 1991; Corey 2015). However, there are a couple of lines of attack against the Sophists that Plato uses again and again, and which immediately connect them to both the concept of the persona and to the practices of the marketer.

Firstly, then, the Sophist does not have a fixed persona, and this makes him deeply untrustworthy. The best instance of how upsetting Plato finds this is in his dialogue, Gorgias (Gorgias, of course, being one of the greatest Sophist philosophers). Early on, Plato has his fictionalised version of Gorgias recount a story which is ostensibly meant to convince the 
audience of the superiority of rhetoric above all other areas of knowledge but which within Plato's view of the appropriate division of areas of expertise is instead meant to signal the fecklessness of the whole Sophist enterprise. So, Gorgias says,

many a time I've gone with my brother or with other doctors to call on some sick
person who refuses to take his medicine or allow the doctor to perform surgery
or cauterization on him. And when the doctor failed to persuade him, I succeeded,
by means of no other craft than oratory. (Gorgias $456 \mathrm{~b}$ ).

So, the Sophist, as a master of persuasive language and eristic, is able to fool others regarding his place in society, to lead them to make the wrong judgement regarding his expertise, his appropriateness, his nature. The second problem with the Sophists for Plato is that they market their skills. Plato and Socrates did not exchange their knowledge for coin. Sophists are infected by the market in the same way that retailers and merchants are. Gorgias advertises his skills in public displays in order to, effectively, tout for business. Allied to this is that their rhetorical power comes from an appreciation of the market, of their audiences - they must judge what will move an audience and find a way of giving them that most impactfully. They are not seekers after truth or virtue - instead, they seek only victory in discourse. The attention to the audience that the practice of rhetoric enshrines is a result of its existence not just in the metaphorical marketplace of ideas, but in the actual marketplace of tutors for hire. Inevitably, this embedding in the market means that their 'truths' will change from audience to audience, from job to job.

The Sophist and the marketer are both infected by the necessities of the market. They have no fixed persona and are instead reacting to the deep appetites of their consumers. The Sophist adopts, for rhetorical convenience, any persona that is needed to win any argument at any particular time and so subverts the very idea of persona as an expression of inner nature. Similarly, the market always threatens to subvert the idea of persona because it can so easily overwhelm those who deal with it - taking them away from their real natures and the roles in society that those natures are aligned with and obsessing them with the vicissitudes of market flow. That is why Plato gives the role of marketer only to those who are outside the City, because the loss of their natures is not of value.

What exactly does this make of the market, itself? This source of obsessional, wrecking power that makes both Sophists and marketers so dangerous to the proper functioning of the City? Returning to a Jungian perspective, we might suggest that the market is, in fact, some form of figuration of the anima. A liquid, flowing, unreliable, amorphous power that threatens to constantly upset, to overcome, the rigid mask-play of social roles. The market overpowers persona - most centrally, continuing the Jungian dynamic, by not being what the persona is, by instantiating all that it is not and so opening the persona to the "dark incalculable power of the unconscious" (Jung 1972, p. 316).

\section{ANIMA AND THe MARKETING PROMise}

As indicated at the start of the article, the promise is the central mode of marketing and although it has been rhetorically reconfigured into the more techno-bureaucratic term, proposition, its basis in the dynamic of allure, seduction, persuasive offering, or even pleasing argument, is never fully elided. At the same time, we should remember that a promise is a point of mediation between a present and a possible future. The marketing promise/proposition can be seen to function as a liminal gateway between possible personas. And while this might seem to be an alluring, attractive prospect its existence, particularly its existence as a managerial strategy continually operating upon us (as consumers), also threatens to undercut the very idea of persona as a fixed identity. The potentialities of the market represent all the things we are not, 
or not quite. They therefore are projections of the anima. Raffay (2000) notes that in Hillman's classic study of the anima concept the latter found "439 extracts from Jung's writings on the anima - and Jung made precisely that many different statements about it" - she "is Eros, she is the anima mundi, she represents the inferior function, she is a fascinosum, darkness, a life-giving daemon, a witch, an intermediary affording access to the unconscious [...], a mysterious lover, a great female magician, the mystical flower of the soul, and a deceiver who entangles people in chaos and must be obeyed" (p. 545). For Jung, the anima is part of us which we must seriously, carefully, work to integrate into our consciousness. Our social selves must be informed by, and balanced by, an open-eyed appreciation of our anima. Yet, it is all too easy to take the route of turning away from it, burying ourselves in the more immediate 'reality' of our persona. Something that results, predictably, in imbalance.

When presented with the promises of marketing we are both seduced and discomforted - we recognise the mysterious signs of our alluring Other, fall prey to the imagery of our unconscious, and imagine the prospect of becoming what we are now not. Marketing tries to show us what we could be, how we might lead our lives, it offers us emotions and experiences that are outside of our quotidian routines but which resonate with deep needs inside us, needs which are often at odds with our persona, our adopted role in society. Increasingly, even, marketing has been instrumental in persuading us that we can have multiple personas, each with its wardrobe, paraphernalia, and appetites - 'treat your inner child with that Playstation', 'acknowledge your inner flirt with that mesh top', 'satisfy your inner tactical operator with that 34 tool multi-knife', 'release your inner witch with this beautiful re-design of the Rider-Waite Tarot'.

Yet, the more consumers are told that they can be anything they want to be, in series or in parallel, at any time of the day, to become what Simmons (2008) calls the "internet chameleon" of "the postmodern consumer", the more the matter of authenticity, of being true to oneself, becomes a burning issue, just as if was for Plato (in adopting a role in society that reflects one's true "nature") and for Jung (in pursuing the "masterpiece" work of integrating anima/animus and persona). So, while Marshall and Barbour (2015) have assured us that "persona-making as a practice is, in short, in pandemic" (p. 9), the victims of that pandemic are increasingly seeking an authenticity behind the mask. As Holt (2002) notes, "post-modern consumers perceive modern branding efforts to be inauthentic because they ooze with the commercial intent of their sponsors" (p. 83). This is echoed in Banet-Weiser's (2012) argument that "the $21^{\text {st }}$ century is an age that hungers for anything that feels authentic, just as we lament more and more that it is a world of inauthenticity" (p. 3). We are concerned with finding authenticity in our own selves and life choices as well as in those whom we choose to align with or support, and in the causes we espouse. Yet, ironically, that search for authenticity is most often pursued through an attention to superficial "authenticity markers" (Enli 2017). We look to the immediately available evidence to evaluate authenticity rather than spending the time and attention needed to get under the surface of something or someone. And marketing practitioners are aware of this. The constant generation, multiplication, and erasure of personas that marketing practice encourages and embodies are inauthenticity markers. In a judgement that takes us right back to Plato's issue with the marketing intermediary, Kadirov et al. (2014) argue that most consumer "authenticity perceptions refer to a single latent assumption about the marketer's or brand's character: to be able to offer authentic products and services, marketers (or firms) must be an organic part of society" (p. 73-4). The signs of this organic relationship with society are being able "to perform their function of provisioning without pretence", to "not aspire to be more than this", and to "not manipulate citizens and systems for the sake of disproportionate growth or profit" (Kadirov et al. 2014, p. 73-74). We see here such strong echoes of Plato's attitude to marketers, the implications that they are manipulators 
seeking cancerous levels of growth that threaten to overwhelm society and so must be kept as tightly bounded as possible. Kadirov et al. (2014) further note that as consumers have demanded more authenticity from marketers, the latter have responded inauthentically (but perhaps in the only way they know) by "staging" authenticity. This "artifice of claimed authenticity" is described in ways that clearly link it to the adoption of personas - it "includes employees posing as customers writing positive comments about products in blogs and newspapers" and is "simply a mask that conceals the thirst for more profits" (p. 77). The open signs of marketing's fast and loose playing with persona, then, become more and more objects of suspicion and cause for revolt.

Plato's judgement against the Sophist is also one based upon an accusation of inauthenticity. Sophists are not really interested in the truth because they teach and write speeches for hire and they perfect the skills to persuade audiences of whatever happens to be advantageous to them at the time. Plato's judgement against the marketer come from the same place - the marketing function requires dealing with the market and this will inevitably take one away from one's nature and towards an obsession with profit which in turn will make one lose a sense of one's place in society, so much so that one will fall to dissembling and manipulation to close any sale. As Laufer and Paradeise (2016) conclude, "marketing and Sophism correspond across the ages" (p. 12) and "both deny the existence of a reality beyond appearances and treat the variety of beliefs - in God, tradition or reasons - as phenomena" (p. 15). They use that relativistic position to "beguile, to entice, to seduce, to entrap" (Tonks 2002, p. 813). From a Jungian perspective, both Sophism and marketing play inauthentically with persona and anima - instead of leading to an individual integration of the two they promise opportunistic adoption of facets, slivers, or shadows, of each.

\section{CONCLUSION}

While the suspicion of Sophistic practices has become enshrined in language and common usage, the suspicion of marketing is increasing. A recent Deloitte Global Survey (Stewart \& Casey 2019) found that $80 \%$ of adults in North America "used at least one ad-blocking method". In the UK, publishers currently lose almost "£3bn in revenue annually due to adblocking" (Goodfellow 2017). Earlier this year, the Advertising Association (2019) released its latest report on UK public trust in advertising which measured public favourability towards the profession at just 25\%, the lowest out of all industries measured and a figure which has been in steady decline since the 1990s. The report identifies bombardment, repetition, and particularly intrusiveness and the use of suspicious or manipulative techniques as the key elements that drive the lack of trust in advertising. But this suspicion is nothing new. As Sheth and Sisodia (2006) declared in the introduction to their book of collected essays on the issue of consumer trust in marketing, "the more a customer is marketed to, the more frustrated or irritated he or she becomes, and the more manipulated and helpless he or she feels" (p. 4). Barksdale and Darden's (1972) investigation into consumer attitudes to marketing is perhaps the first exploration of this issue within the marketing academy, but their findings simply echo the sort of suspicions and discomforts that we have already seen in Plato and which the Advertising Association's report confirms are still very much the case: "many consumers register a high level of apprehension about certain business policies and considerable discontent about specific marketing activities [...] the most obvious example is the lack of confidence in advertising" (p. 34).

This article has argued that the roots of the wide - and increasing - suspicion of marketing grow from the way in which marketing seeks to play with our relationship to persona and anima. From Jung's perspective what we should be doing with our anima is developing a 
healthy relationship with it, engaging in an exploratory, revealing, constructive dialogue with it in order to integrate our persona and our Other. But this is not the aim of marketing, which instead encourages us to confuse persona and anima in an ever-shifting flow of identity-play through consumption. Each day we are offered countless value propositions that have been mediated by marketing agents whose very professional identity is embedded in an orientation towards persona as a shifting, reactive cavalcade (Diona \& Arnould 2016; Lair et al. 2005; Mackey 2016; Press \& Arnould 2014; Simmons 2008; Stern 1993). That constant stream of propositions, of promises, is an endless fountainhead of un-reflected upon, un-integrated anima presented as fast-fashion, prêt-à-porter personas.

In this sense, the central dynamic of marketing is the persuasive construction of each purchase and service-provision opportunity as promising a chance to wear another mask which might reflect something of our deeper, Other self. This also seems to, at least momentarily, satisfy some part of our need to commune with our unconscious, but which diverts us from any chance of real dialogue, real exploration, real integration with it. Each persona is trapping us instead in the one social identity that we must never give up - the dutiful consumer.

\section{END NOTES}

i All references to Plato's works are to the following edition: Plato (1997) (John Cooper, ed.) Collected Works, Hackett Publishing, Indianapolis.

\section{WORKS CITED}

Advertising Association 2019, Arresting the Decline of Public Trust in Advertising. Retrieved $1^{\text {st }}$ June 2019 from <https://www.adassoc.org.uk/policy-areas/report-arresting-thedecline-of-public-trust-in-uk-advertising/>

American Marketing Association 2019, The Definition of Marketing. Retrieved 14th July 2020 from <https://www.ama.org/the-definition-of-marketing/>

Banet-Weiser, S 2012, Authentic ${ }^{T M}$ : the politics of ambivalence in a brand culture, New York University Press, New York.

Barksdale, H and Darden, W 1972, 'Consumer Attitudes Toward Marketing and Consumerism'. Journal of Marketing, vol. 36, no. 4, pp. 28-35.

Belk, RW 1991, 'The Ineluctable Mysteries of Possessions', Journal of Social Behavior and Personality, vol. 6, no. 6, pp. 17-55.

Belk, RW, Wallendorf, M, \& Sherry Jr, JF 1989, 'The Sacred and the Profane in Consumer Behavior: Theodicy on the Odyssey', Journal of Consumer Research, vol. 16, June, pp. 138.

Belk, RW, Ger, G, \& Askegaard, S 2003, 'The Fire of Desire: A Multisited Inquiry into Consumer Passion', Journal of Consumer Research, vol. 30, December, pp. 326-351.

Beltramini, RF 2003, 'Advertising Ethics: The Ultimate Oxymoron?' Journal of Business Ethics, vol. 48, no. 3, pp. 215-216.

Blackshaw, P 2008, 'Marketers Love Conversation, Unless the Consumer Starts It', Advertising Age, retrieved 1 September 2020 from <https://adage.com/article/digitalcolumns/marketers-love-conversation-consumer-starts/130271>

Campbell, J 2008, The Hero with a Thousand Faces, New World Library, Novato, CA.

Cole, T 1991, The Origins of Rhetoric in Ancient Greece, John Hopkins University Press, Baltimore.

Critser, G 2003, Fat Land: How Americans Became the Fattest People in the World, Penguin, London.

Corey, D 2015, The Sophists in Plato's Dialogues, State University of New York Press, Albany, NY.

Dion, D and Arnould, E 2016, 'Persona-fied brands: managing branded persons through persona', Journal of Marketing Management, vol. 32, no. 1-2, pp. 121-148. 
Duncan, T \& Moriarty, SE 1998, 'A communication-based marketing model for managing relationships', Journal of Marketing, vol. 62, no. 2, pp. 1-13.

Enli, G 2017, 'Twitter as an arena for the authentic outsider: exploring the social media campaigns of Trump and Clinton in the 2016 US presidential election', European Journal of Communication, vol. 32, no. 1, pp. 50-61.

Ewen, S 2001, Captains of Consciousness: Advertising and the Social Roots of the Consumer Culture, Basic Books, New York.

Germann, F, Ebbes, P \& Grewal, R 2015, The Chief Marketing Officer Matters! Journal of Marketing, vol. 79, no. 3, pp. 1-22.

Goodfellow, J 2017, 'UK publishers lose nearly $£ 3$ bn in revenue annually due to adblocking', The Drum, October 11, 2017, retrieved 6 June 2019 from

$<$ https://www.thedrum.com/news/2017/10/11/uk-publishers-lose-nearly-3bnrevenue-annually-due-adblocking $>$

Grönroos, C 1994, 'From Marketing Mix to Relationship Marketing: Towards a Paradigm Shift in Marketing', Management Decision, vol. 32, no. 2, pp. 4-20.

Grönroos, C 2004, 'The relationship marketing process: communication, interaction, dialogue, value', Journal of Business \& Industrial Marketing, vol. 19, no. 2, pp. 99-113.

Grönroos, C 2011, 'A service perspective on business relationships: The value creation, interaction and marketing interface', Industrial Marketing Management, vol. 40, no. 2, pp. 240-247.

Gummesson, E 1987, 'The new marketing-Developing long-term interactive relationships', Long Range Planning, vol. 20, no. 4, pp. 10-20.

Gummesson, E 2008, 'Customer centricity: reality or a wild goose chase?' European Business Review, vol. 20, no. 4, pp. 315-330.

Heath, T, Cluley, R and O'Malley, L 2017, 'Beating, ditching and hiding: consumers' everyday resistance to marketing', Journal of Marketing Management, vol. 33, no. 15-16, pp. 12811303.

Holt, D. 2002, 'Why Do Brands Cause Trouble? A Dialectical Theory of Consumer Culture and Branding', Journal of Consumer Research, vol. 29, no. 1, pp. 70-90.

Jhally, S 1990, The Codes of Advertising: Fetishism and the Political Economy of Meaning in the Consumer Society, Routledge, New York.

Jung, C 1972, The Collected Works of C. G. Jung Volume 7. G Adler and RFC Hull (Eds. and Trans.), Princeton University Press, Princeton.

Kadirov, D, Varey, R and Wooliscroft, B 2014, 'Authenticity: A Macromarketing Perspective', Journal of Macromarketing, vol. 32, no. 1, pp. 73-79.

Klein, N 2009, No Logo, Picador, New York.

Laufer, R \& Paradeise, C 2016, Marketing Democracy: Public Opinion and Media Formation in Democratic Societies, Transaction Publishers, London.

Layton, R 2011, 'Marketing: Is management all that there is?' Journal of Historical Research in Marketing, vol. 3, no. 2, pp. 194-213.

Lanning, M \& Michaels, E 1988, 'A Business is a Value Delivery System', McKinsey Staff Paper, No. 41. (June), pp. 1-16.

Mackey, S 2016, 'Persona - an old public relations problem?' Persona Studies, vol. 2, no. 1, pp. 84-96.

Malkan, S 2007, Not Just a Pretty Face: The Ugly Side of the Beauty Industry, New Society Publishers, Gabriola Island.

Marshall, PD \& Barbour, K 2015, 'Making Intellectual Room for Persona Studies: a new consciousness and a shifted perspective', Persona Studies, vol.1, no. 1, pp. 1-12.

Miles, C 2016, 'Control and the Rhetoric of Interactivity in Contemporary Advertising Theory and Practice', in J Hamilton, R Bodle and E Korin (eds.), Explorations in Critical Studies of Advertising, Routledge, London, pp. 110-123.

Moss, M 2013, Salt, Sugar, Fat: How the Food Giants Hooked Us, WH Allen, London.

Nath, P \& Mahajan, V 2008, 'Chief marketing officers: a study of their presence in firms' top management teams', Journal of Marketing, vol. 72, no. 1, pp. 65-81. 
Otnes, C \& Scott, LM 1996, 'Something Old, Something New: Exploring the Interaction Between Ritual and Advertising', Journal of Advertising, vol. 25, no. 1, pp. 33-50.

Press, M \& Arnould, EJ 2014, 'Narrative transparency', Journal of Marketing Management, vol. 30, no. 13-14, pp. 1353-1376.

Raffey, A 2000, 'Why it is difficult to see the anima as a helpful object: critique and clinical relevance of the theory of archetypes', Journal of Analytical Psychology, vol. 45, no. 1, pp. 541-560.

Sasser, SL 2008, 'Creating passion to engage versus enrage consumer co-creators with agency co-conspirators: unleashing creativity', Journal of Consumer Marketing, vol. 25, no. 3, pp. 183-186.

Schlosser, E 2002, Fast Food Nation: What the All-American Meal Is Doing to the World, Penguin, London.

Sheth, J \& Sisodia, R 2006, 'Introduction', in J. Sheth and R. Sisodia (eds.), Does Marketing Need Reform? Fresh Perspectives on the Future, Routledge, London, pp. 3-11.

Simmons, G 2008, 'Marketing to postmodern consumers: introducing the internet chameleon'. European Journal of Marketing, vol. 42, no. 3/4, pp. 299-310.

Stern, B 1993, 'The firm, the author, and the persona: A literary model of the source of advertising', Journal of Current Issues and Research in Advertising, vol. 15, no. 2, pp. 1524.

Stewart, D \& Casey, M 2019, 'Are Consumers 'Adlergic'? A Look at Ad-Blocking Habits'. Wall Street Journal, retrieved $15^{\text {th }}$ May 2019 from $<$ https://deloitte.wsj.com/cmo/2018/04/03/are-consumers-adlergic-a-look-at-adblocking-habits/>

Tonks, D 2002, 'Marketing as Cooking: The Return of the Sophists', Journal of Marketing Management, vol. 18, no. 7-8, pp. 803-822.

Vargo, SL \& Lusch, RF 2004, 'Evolving to a New Dominant Logic for Marketing', Journal of Marketing, vol. 68, no. 1, pp. 1-17.

Vargo, SL \& Lusch, RF 2017, 'Service-dominant logic 2025'. International Journal of Research in Marketing, vol. 34, no. 1, pp. 46-67.

Vigneron, F \& Lester WJ 1999, 'A Review and a Conceptual Framework of Prestige-Seeking Consumer Behavior', Academy of Marketing Science Review, vol. 3, no. 1, pp. 1-15

Williams, R 1980, Problems in Materialism and Culture, Verso, London.

Williamson, J 2002, Decoding Advertisements: Ideology and Meaning in Advertising, Marion Boyars, London.

Woodside, AG, Megehee, CM \& Sood, S 2012, 'Conversations with(in) the collective unconscious by consumers, brands, and relevant others', Journal of Business Research, vol. 65, no. 5, pp. 594-602.

Zwick, D \& Bradshaw, A 2019, 'Biopolitical Marketing and the Commodification of Social Contexts', in M Tadajewski, M Higgins, J Denegri-Knott, and R Varmin (eds.) The Routledge Companion to Critical Marketing, 430-438. Routledge, London. 